\title{
REAL WAGES OF LITHUANIAN CONSTRUCTION WORKERS FROM 1913 TO 1939 (MEASURED IN SUBSISTENCE AND WELFARE RATIOS) IN A CROSS-NATIONAL COMPARISON*
}

\author{
Zenonas Norkus, \\ Aelita Ambrulevičiūtè, \\ Jurgita Markevičiūtè \\ (Institute of Sociology and Social Work, Vilnius University)
}

\begin{abstract}
This article provides two comparisons: (1) a cross-time comparison of real wages of skilled and unskilled workers in Kaunas before the First World War and during the interwar period; and (2) a cross-national quantitative comparison of the wages of unskilled workers in Kaunas and the capital cities of most European countries during the same period. For the second comparison, we use the findings of researchers who applied Robert $C$. Allen's methodology of real wage estimation. In this methodology, the wages of unskilled construction workers (known in interwar Lithuania as zimagoras) are used as proxies for the wages of unskilled urban workers, and those of construction site carpenters provide a sample for skilled workers' wages. Real wages are measured in subsistence and welfare ratios, indicating the distances separating the purchasing power of wages from the subsistence level of a single worker (subsistence ratio = 1 meaning absolute poverty) or his family (welfare ratio $=1$ meaning absolute poverty). Subsistence or absolute poverty levels are defined by regionally adjusted (to variations in survival needs) minimum consumption baskets. The main findings are: (1) although during the first decade of independence (in the 1920s) the real wages of unskilled construction workers in Kaunas were lower than in 1913, by 1938 they had markedly surpassed the pre-First World War level; (2) in no year with available data did the real wages of unskilled construction workers in Kaunas fall below the absolute poverty level; (3) the real wages of skilled construction workers in Kaunas had markedly surpassed the pre-First World War level even before the Great Depression in the early 1930s, and remained above this level even in the worst years of the depression; (4) the real wages of skilled and unskilled construction workers in Kaunas in 1913 were no
\end{abstract}

* This project received funding from the European Social Fund (Project No 09.3.3-LMT-K-712-01-00o6) under the grant agreement with the Research Council of Lithuania (LMTLT). 
lower than in metropolitan centres of the Russian Empire; (5) in the period 1927 to 1929, the wages of unskilled construction workers in Kaunas were lower than in Moscow, but largely surpassed Russian wages in the 1930s, when Stalin's policy of industrialisation forced them below the subsistence level; (6) the real wages of unskilled construction workers in Kaunas in the 193os surpassed those in Riga and Tallinn. While this finding is surprising, it concurs with earlier (2007) findings by Gediminas Vaskela, who compared the mean wages of workers and employees in the Baltic countries in the period 1938 to 1940.

KEYWORDS: real wages in Kaunas 1913 to 1939; real wages in European capital cities 1913 to 1939; real wages in subsistence ratios; real wages in welfare ratios; skilled workers; unskilled workers; absolute poverty.

\section{Introduction}

The aim of this article is to apply the innovative methodology in the measurement of real wages invented by Robert C. Allen, a leading contemporary economic historian of Canadian origin, in the estimation of the quality of life and changes in it in the interwar Republic of Lithuania. As will be explained in the first section, the use of wages in the construction sector as proxies for the wages of all waged workers is a central part of this methodology. Therefore, the use of construction workers' wages as a sample should not mislead us to believe that the findings of this study lack a broader relevance. To the contrary, according to Allen's assumption, they extend to the whole urban sector of early modern and modernising economies, including interwar Lithuania.

Although real wages are one of the central topics in socio-economic history, little is known about their dynamics in interwar Lithuania. This may appear odd in view of the role bestowed on the working class in Marxism, which was imposed on Lithuanian historians as an obligatory conceptual framework during the Soviet occupation. However, Soviet-era research could not contribute much to the knowledge of the real economic situation of waged workers in interwar Lithuania. ${ }^{1}$ Historians working in occupied

${ }^{1}$ Z. Balevičius, Darbininku išnaudojimas buržuazinèje Lietuvoje (Vilnius, 1950); Z. Balevičius, Darbininku padètis buržuazinèje Lietuvoje (Vilnius, 1960); A. Gaigalaitė, Darbininku judëjimo pakilimas Lietuvoje 1929-1934 metais (Vilnius, 1957); Š. Fridbergas, Buržuazinès Lietuvos pramoné (Vilnius, 1988), pp. 43-48. 
Lithuania were ideologically obliged to show that the worker's lot only deteriorated during the capitalist development of independent Lithuania (1918-1940), leading to the 'socialist revolution'. So they could only be very selective in publications about their findings, which do not provide a reliable representation of the real situation. Even more importantly, historical sources do not provide information about real wages. They report nominal wages, while real wages are defined by their purchasing power, or the total amount of goods and services that can be bought with a wage. Only real wages are cross-time comparable. To find out how much real wages have changed, nominal wages should be adjusted for inflation or deflation. Cross-national comparisons of real wages are even more complicated. The conversion of nominal wages to numéraire currency at the currency exchange rate does not show the real extent of wage differences between countries, because a valid cross-national comparison of wages should take into account differences in the costs of living in different countries.

Soviet-era researchers simply did not use the econometric tools required to extract information from sources about real wages. They are also not used in recent work resuming research in the social history of interwar Lithuania after a prolonged break. ${ }^{2}$ This work uses mainly qualitative evidence and qualitative methods for processing, providing valuable information about the subjective experiences of waged workers and a reflection of their situation in various media and discourses in interwar times. However, qualitative methodology cannot provide reliable conclusions about trends in changes in real wages, or about the relative standing of Lithuanian wages in an international context, meeting the standards of contemporary quantitative (cliometric) economic history. ${ }^{3}$

Until now, only one contribution of such a kind has been published on the economic history of interwar Lithuania. In his

${ }^{2}$ N. Černiauskas, Nedarbas Lietuvoje 1918-1940 metais (Vilnius, 2014); U.M. Andrijauskaitè, Miestu darbininkai ir organizuotas darbo judejjimas Lietuvoje 1918-1940 m. (Kaunas, 2017); D. Bukelevičiūtė, Z. Butkus et. al., Socialiniai pokyčiai Lietuvos valstybëje 1918-1940 (Vilnius, 2016).

${ }^{3}$ E.g.: Handbook of Cliometrics, C. Diebolt, C. and M. Haupert (eds.) (New York, 2016). 
pioneering study, Gediminas Vaskela compared the salaries and the standard of living of workers' and employees' families in Lithuania, Latvia and Estonia in the period 1938 to $1940 .{ }^{4}$ Our study encompasses a longer period of time, and extends to a larger number of countries. We start in 1913, because that is the base year used in statistical publications of the independent Republic of Lithuania, and also in international economic historiography. We will answer the following research questions about workers' wages in interwar Lithuania: were real wages in interwar Lithuania lower or higher compared with 1913? When, if at all, did they exceed the prewar level? How were they affected by the economic depression of 1931 to 1935 ?

In answering these questions, we contribute to cross-national comparative quantitative research in European economic history. The economic history of Lithuania is still one of the few remaining 'blank spots', because of the absence of relevant historical statistical data on the country in databases used by the international research community. Recent extensions of the international data infrastructure for cross-country comparative socio-economic research includes the data collection 'Building Labourers' Real Wages, $1820-2010^{\prime 5}$ collected by a group of Dutch scholars led by Pim de Zwart, implementing the international, inter-disciplinary Clio-Infra project sponsored by the Organisation for Economic Cooperation and Development (OECD) as part of the broader 'Better Life Initiative', which was launched by Angel Gurría, the secretary-general of the OECD, in $2011 .{ }^{6}$ We use data from this data collection for a cross-country comparison of workers' wages in interwar Lithuania. To arrive at comparable real wage data for Lithuania, we follow as closely as possible the real wage estimation procedures applied by de Zwart's team, who, in their turn, followed

${ }^{4}$ G. Vaskela, 'Darbo užmokestis ir darbininkų bei tarnautojų šeimų gyvenimo lygis Lietuvoje, Latvijoje ir Estijoje 1938-1940 metais', Lituanistika, vol. 53, 4 (72) (2007), pp. 19-35.

${ }^{5}$ P. de Zwart, B. van Leeuwen, J. Van Leeuwen-Li, 'Labourers Real Wage' (2015), http://hdl.handle.net/10622/QK8VRF (accessed: 2019-o8-26), IISH Dataverse, V1.

${ }^{6}$ How Was Life?: Global Well-being since 1820, J.L van Zanden, et al. (eds.) (Paris, 2014). 
the guidelines of R.C. Allen. ${ }^{7}$ This makes our findings comparable with those of Allen's broader school, including scholars who work on cross-country comparative historical research on the reward of labour, applying his methods.

We start with an exposition of these methods. In the second section, we present our nominal wage and consumption goods price data. In the third, we present our findings and use them for cross-comparisons of workers' wages in Lithuania, drawing on the work of Allen and his school. We close with a description of tasks for further research.

\section{Robert C. Allen's methodology of real wage measurement}

Before Allen's landmark contributions, the mainstream approach to the history of real wages was based on the deflation of nominal wages by the consumer price index (CPI), involving the recalculation of the purchasing power of wages in constant prices (those of a selected base year). ${ }^{8}$ The cross-country comparison of real wages also needs data to establish the purchasing power parities (PPP) of different currencies. This makes the application of this approach difficult for the period before 1945, when there are only very few calculations of the PPP. These difficulties are ingeniously circumvented in the Allen method, which is conceptually grounded in ideas of 'absolute poverty' or the 'subsistence wage', which have been used in economic science since its very beginning in the 18 th century.

${ }^{7}$ R.C. Allen, 'The Great Divergence in European Wages and Prices from the Middle Ages to the First World War', Explorations in Economic History, vol. 38 (4) (2001), pp. 11-447; R.C. Allen 'India in the Great Divergence', The New Comparative Economic History: Essays in Honor of Jeffery G. Williamson, T.J. Hatton, K.H. O’Rourke, A.M. Taylor (eds.) (Cambridge, 2007), pp. 9-32; R.C. Allen, The British Industrial Revolution in Global Perspective, 6th printing (Cambridge, 2012); R.C. Allen, J.P. Bassino, M. Debin, C. Moll-Murata, J. Luiten van Zanden, 'Wages, Prices, and Living Standards in China 1738-1925: In Comparison with Europe, Japan, and India', Economic History Review, vol. 64, (2011), pp. 8-38; R.C. Allen, T. Murphy, E. Schneider, 'The Colonial Origins of Divergence in the Americas: A Labour Market Approach', Journal of Economic History, vol. 72 (2012), pp. 863-894.

${ }^{8}$ e.g.: P. Scholliers, V. Zamagni, Labour's Reward. Real Wages and Economic Change in 19th and 2oth-century Europe (Aldershot, 1995). 
Contemporary economic and demographic historians agree that the economic history of mankind broadly divides into Malthusian and post-Malthusian (also known as the Solow phase) periods, with a transition phase in between. ${ }^{9}$ This consensus includes the view that in the Malthusian phase, the wages of the majority (non-elite) of the population fluctuated around the subsistence wage level, approaching it in overpopulated areas, and increasing in periods or areas with less pressure by the population on scarce resources. Large parts of the populations of underdeveloped countries still live on a subsistence wage, meaning absolute poverty. In advanced countries, absolute poverty occurs only as an exception. The main social problem in these countries is usually relative poverty, measured as the percentage of the population with an income less than a fixed proportion of the median income.

Relative poverty is socially defined, and depends on the social context. Absolute poverty is less so, because it refers to the income level necessary for biological survival and physical work, involving the intake of some minimal quantity of calories (which can be established by human biology or nutritional science), and the satisfaction of other biological survival needs. Allen's basic idea is that real wages can be measured in the cross-country and crosstime comparative way by expressing nominal wages in subsistence ratios. ${ }^{10}$ They show how many consumption baskets, including only goods necessary for bare survival, a wage earner can afford to buy for his/her nominal wage. In other words, subsistence ratios show how many times a wage earner was above the absolute poverty line in a specific country at a specific time.

Although ideas of subsistence wages and absolute poverty are as old as economic science, little effort has been made to quantify

${ }^{9}$ e.g.: G. Clark, A Farewell to Alms. A Brief Economic History of the World (Princeton, 2007); R.W. Fogel, The Escape from Hunger and Premature Death, 1700-2100. Europe, America and the Third World (Cambridge, 2004); O. Galor, Unified Growth Theory (Princeton, 2011).

${ }^{10}$ R.C. Allen, 'Absolute Poverty: When Necessity Displaces Desire', American Economic Review, 107 (12) (2017), pp. 369o-3721; A. Deaton, 'Price Indexes, Inequality, and the Measurement of World Poverty', American Economic Review 100 (1) 2010, pp. 5-34. 
and operationalise them. The sustained effort to accomplish this is one of Allen's several distinctive contributions to economic history. In this effort, which has been going on now for nearly two decades, Allen has made several updates and clarifications. We base the application of his methods on wage and price data in Lithuania in 1913 to 1939 on his most recent specifications of the consumption baskets we were able to find. ${ }^{11}$

Table 1. The contents of subsistence baskets in selected countries and regions. ${ }^{12}$

\begin{tabular}{|c|c|c|c|c|c|c|c|}
\hline \multicolumn{2}{|c|}{$\begin{array}{l}\text { Northeast Europe } \\
\text { (de Zwart) }\end{array}$} & \multicolumn{2}{|c|}{$\begin{array}{l}\text { Northwest Europe } \\
\text { (Allen) }\end{array}$} & \multicolumn{2}{|c|}{$\begin{array}{l}\text { Russia } \\
\text { (Allen and } \\
\text { Khaustova) }\end{array}$} & \multicolumn{2}{|c|}{$\begin{array}{l}\text { Northern China } \\
\text { (de Zwart and } \\
\text { Allen) }\end{array}$} \\
\hline Rye bread & $178 \mathrm{~kg}$ & Oats & $155 \mathrm{~kg}$ & $\begin{array}{l}\text { Rye } \\
\text { bread }\end{array}$ & $267 \mathrm{~kg}$ & Sorghum & $179 \mathrm{~kg}$ \\
\hline $\begin{array}{l}\text { Beans / } \\
\text { peas }\end{array}$ & $20 \mathrm{~kg}$ & $\begin{array}{l}\text { Beans / } \\
\text { peas }\end{array}$ & $20 \mathrm{~kg}$ & Potatoes & $50 \mathrm{~kg}$ & $\begin{array}{l}\text { Beans / } \\
\text { peas }\end{array}$ & $20 \mathrm{~kg}$ \\
\hline Meat & $3 \mathrm{~kg}$ & Meat & $5 \mathrm{~kg}$ & Meat & $5 \mathrm{~kg}$ & $\begin{array}{l}\text { Meat / } \\
\text { fish }\end{array}$ & $3 \mathrm{~kg}$ \\
\hline Butter & $3 \mathrm{~kg}$ & $\begin{array}{l}\text { Butter / } \\
\text { oil }\end{array}$ & $3 \mathrm{~kg}$ & $\begin{array}{l}\text { Butter / } \\
\text { oil }\end{array}$ & $3 \mathrm{~kg}$ & $\begin{array}{l}\text { Oil / } \\
\text { ghee }\end{array}$ & $3 \mathrm{~kg}$ \\
\hline Soap & $1.3 \mathrm{~kg}$ & Soap & $1,3 \mathrm{~kg}$ & Soap & $1.3 \mathrm{~kg}$ & Soap & $1.3 \mathrm{~kg}$ \\
\hline Cloth & $3 \mathrm{~m}$ & Cloth & $3 \mathrm{~m}$ & $\begin{array}{l}\text { Cloth } \\
\text { (cotton) }\end{array}$ & $53 \mathrm{~m}$ & Cloth & $3 \mathrm{~m}$ \\
\hline Candles & $1.3 \mathrm{~kg}$ & Candles & $1.3 \mathrm{~m}$ & \multirow[t]{2}{*}{ Lighting } & \multirow{2}{*}{$\begin{array}{l}0.9 \\
\text { mBTU }\end{array}$} & Candles & $1.3 \mathrm{~kg}$ \\
\hline $\begin{array}{l}\text { Lamp oil } \\
\text { (kerosene) }\end{array}$ & 1.3 litre & Lamp oil & 1.3 litre & & & Lamp oil & 1.3 litre \\
\hline Fuel & $\begin{array}{l}3.0 \\
\text { mBTU }\end{array}$ & Fuel & $\begin{array}{l}2.0 \\
\text { mBTU }\end{array}$ & Fuel & $\begin{array}{l}12 \\
\mathrm{mBTU}\end{array}$ & Fuel & \begin{tabular}{|l|l}
2.0 \\
$\mathrm{mBTU}$
\end{tabular} \\
\hline Housing & $\begin{array}{l}5 \% \text { of } \\
\text { basket } \\
\text { cost }\end{array}$ & Housing & $\begin{array}{l}5 \% \text { of } \\
\text { basket } \\
\text { cost }\end{array}$ & Housing & $3 \mathrm{~m}^{2}$ & Housing & $\begin{array}{l}5 \% \text { of } \\
\text { basket } \\
\text { cost }\end{array}$ \\
\hline
\end{tabular}

${ }^{11}$ R.C. Allen, The British Industrial Revolution in Global Perspective (Cambridge, 2012), p. 37; R.C. Allen, E. Khaustova, 'Russian Real Wages Before and After 1917: in Global Perspective', University of Oxford, Discussion Papers in Economic and Social History, 158 (July, 2017), pp. 13-14.

${ }^{12}$ P. de Zwart, B. van Leeuwen, J. van Leeuwen-Li, 'Real wages since 1820', How Was Life?: Global Well-being since 1820, van Zanden, J.L., et al. (eds.) (Paris, 2014), p. 75; R.C. Allen, The British Industrial Revolution in Global Perspective, p. 37; R.C. Allen, E. Khaustova, 'Russian Real Wages Before and After 1917: in Global Perspective', pp. 13-14. 
Table 1 provides a description of Allen's main measurement tool, the bare subsistence basket. It includes the consumption goods necessary for an adult man to survive at the absolute poverty level. The figures in the table refer to the quantities of these goods consumed during one year. The main part of this basket are foods providing 1,900 to 2,100 kilocalories ( $\mathrm{kcal}$ ), and at least 40 grams of protein per day. There are four types of foods in the basket: carbohydrates, vegetables (beans, peas or potatoes), meat or fish, and fat. The main staple is the cheapest sort of cereals, providing carbohydrates. In fact, many regional versions of the subsistence basket are applied by researchers of the Allen school, which are equivalent by nutritional value, but differ in composition across different regions.

Table 1 shows the contents of four regionally specific baskets, including not only baskets we will apply in our study (de Zwart's for northeast Europe, and Allen's and Khaustova's for Russia), but also two for other regions, to provide a better understanding of Allen's procedure. All regionally specific baskets include only foods inexpensively satisfying basic nutritional needs, and reflecting the eating habits of poor people in different places. Therefore, the main staple in northern China is sorghum, in southern China and India rice, and in Latin America and southern Europe maize. Oats are considered by Allen the main staple in northwest Europe, as is rye bread in northeast Europe and Russia. Protein is provided by beans or peas, and beef or pork in Europe, and fish in India and China. The last kind of food in the subsistence food basket is fat, provided by oil, or butter (in northern Europe).

The minimum subsistence basket also includes small quantities of clothing, lighting and fuel. For some reason, Allen's basket includes two items of lighting (candles and lamp oil), although they are substitutes, while fuel is specified only in British thermal units (BTU). This is a traditional scientific unit of heat, defined as the amount of heat required to raise the temperature of one pound of water by one degree Fahrenheit. Allen's own minimum subsistence basket for northwest Europe includes the quantity of fuel necessary to produce two million BTU ( 2 mBTU). This quantity 
of heat is produced, for example, by 100 kilograms of coal or o.34 cubic metres of birch firewood. ${ }^{13}$

These quantities of fuel may be sufficient for cooking, but are not adequate for countries where heating the living space is necessary to survive during the cold season. To survive in regions with large seasonal weather changes, larger quantities of clothing are also needed. For this reason, in recent work on real wages in Russia, done in collaboration with the Russian scholar Elena Khaustova, ${ }^{14}$ Allen significantly increased the quantity of fuel and clothes in the version of the subsistence basket, reflecting minimal survival needs under the climatic conditions in that country. In this basket, the cost of 53 square metres of coarse cotton cloth also covers expenditure on footwear and bedding, which is also much higher in the Russian climate. Another peculiarity of the Russian subsistence basket is the definition of lighting needs not in units of weight of substances providing light, but directly in heat units, also allowing its application to other countries. The annual lighting need is set as amounting to o.9 mBTU, which is the equivalent energy of three hours of light every night a year from a candle or an electric light bulb. ${ }^{15}$ Potatoes replace peas or beans in this basket, representing the vegetable part of the subsistence diet.

In our study, we will measure wages in interwar Lithuania, applying both de Zwart's basket for northeast Europe, used in his research for the Clio-Infra project, and Allen's own recent basket for Russia. Substantively, the last basket seems to reflect the survival needs and eating habits of poor people in Lithuania better than de Zwart's basket, which differs only slightly from Allen's own basket for northwest Europe. De Zwart increases the quantity

${ }^{13}$ https://www.uwsp.edu/cnr-ap/KEEP/nres633/Pages/Unitı/Supplementary\%20 Pages/Energy-Conversion-and-Resource-Tables.aspx (accessed: 2019-o8-26).

Together with de Zwart, we used information provided in this source to calculate the quantities of birch firewood and paraffin necessary to provide quantities of heat specified in Table 1.

${ }^{14}$ R.C. Allen, E. Khaustova, 'Russian Real Wages Before and After 1917: in Global Perspective'.

${ }^{15}$ Ibidem, p. 6. 
of fuel in the bare subsistence basket from two to three million BTU, but decreases the quantity of meat by two kilograms (from five to three kilograms). Rye bread and potatoes were traditional main staples in the diet of poor people in Lithuania as well as in Russia, while heating and apparel needs were no less in Lithuania than in Russia. Allen and Khaustova use this modified basket to compare real wages in the period 186o to 1937 in Russia (Moscow and St Petersburg), the USA (Boston), and the UK (Manchester). The use of the Russian basket will allow us to compare wage levels in Lithuania with those in Russian metropolitan cities in 1913 and after the Bolshevik revolution.

Although de Zwart's subsistence basket for northeast Europe is unrealistic about the minimal survival needs of the poorest people under Lithuanian conditions, it allows for a comparison of wage levels in Lithuania with a much broader range of countries during a longer period (see Table 6 below). Inconveniently, de Zwart's data collection does not include Russia. However, interwar Estonia and Latvia are present, allowing also for a comparison with the findings of Vaskela's pioneering research. Vaskela compares the mean wages of workers and employees. To enhance the comparability of our findings with those of Allen's school, we will follow Allen's prescription to compare the wages of construction workers.

Even in our times and in the most advanced countries, construction employs large numbers of unskilled workers, whose activities on a construction site have changed little in content and the requisite skills since Medieval times. Both in ancient and modern times, nothing except brute physical force is needed for a male with no vocational education or training to be gainfully employed in construction from the very first day of work. Therefore, Allen assumes that the nominal wages of unskilled workers (known in interwar Lithuanian folklore as zimagoras) in construction are the most representative of the mean level of wages of unskilled workers as such. Concerning skilled workers' wages, Allen claims that woodworking occupations (carpenter or cabinet maker) satisfy best the condition of relative cross-time stability in work content and skills level for their wages to stand as proxy mean wages of skilled manual workers. 
As construction activities go on continuously, the chances of finding nominal wage data for construction workers in archives are particularly high. The chances are largest for big cities, especially capitals, which are always the places with the most active construction activities. In fact, Allen's famous set of data on the wages of building labourers and craftsmen in 17 European cities between 1260 and 1913 includes only data on wages in these places. ${ }^{16}$ To enhance the comparability of their findings with those in Allen's data set, his followers limit their estimations of real wages to the larger (first of all, capital) cities.

Allen's methodology culminates in the idea of the welfare ratio (WR), which is his measure of the worker's standard of living. The WR equals the annual earnings of the worker divided by the cost of maintaining a family of four at subsistence level. To maintain a family at this level, the annual earnings of a worker should exceed the annual cost of the subsistence basket by more than three times. It is assumed that the family, besides the wage earner, includes his wife and two children. While the maintenance of the wife requires a second subsistence basket, the maintenance of one child requires half of it. If the WR equals one, the worker's earnings are just enough for survival at subsistence level. Although this means life in absolute poverty, consumption is still sufficient for the children to grow up, and for the worker to reproduce his labour power. This is no longer the case if the WR sinks below zero. Then a family can survive only if other family members (wife or children) also find employment, or the worker himself works longer. This is not impossible, because Allen assumes that the worker works 250 days a year.

If the WR exceeds one, the family household has a surplus over subsistence. This is usually spent not just on the consumption of larger quantities of goods composing the subsistence basket. Instead, the quality and variety of food is improved, or the housing is improved, which means increasing the standard of living. In his original estimate of the subsistence needs of the four-person family household, Allen (and de Zwart) takes into account the

${ }^{16}$ R.C. Allen, 'Consumer Price Indices, Nominal/Real Wages and Welfare Ratios of Building Craftsmen and Labourers, 126o-1913' (2013), http://www.iisg.nl/hpw/allen. rar (accessed: 2019-08-26). 
expenditure on housing, inflating the cost of the family subsistence basket by $15 \%$, or by $5 \%$ for the single subsistence basket. In his calculation of the cost of the Russian subsistence basket, he uses a different approach, assuming the minimal housing space need for a single person is three square metres. While a single worker can satisfy such a need just by renting a bed in a barracks or a hostel, a family household needs living room of at least 12 square metres So the Russian subsistence basket includes the annual cost of renting such a room for a family household (adding it to the total of the three minimum baskets without housing expenses).

\section{Data on Lithuania}

For the period before the First World War, de Zwart integrated into his Clio Infra building labourer data collection ${ }^{17}$ the data from the collection of Allen himself on wages in 17 European cities from 1260 to 1913 (see previous section). For the interwar period, he could draw on the data collected by the International Labour Organisation (ILO) in the annual survey called the October Inquiry. Its aim is to obtain data on prices and wages across the world. From 1924 till now, national statistics agencies receive two questionnaires from the ILO, one about retail prices and the other about working hours and wages. The processed data is published in the periodicals of the ILO: International Labour Review (1924 to 1945), Yearbook of Labour Statistics (1934 to 1957), Statistical Supplement to the International Labour Review (1951 to 1963), Bulletin of Labour Statistics (since 1964). Initially established as an agency of the League of Nations, the ILO continues its activities as the oldest specialised agency of the United Nations (since 1946). Data from the October Inquiry for the period since 1983 is available online, and is considered the most comprehensive authoritative source of data in labour statistics, encompassing data on nearly all current 187 members of the ILO. ${ }^{18}$

${ }^{17}$ P. de Zwart, et al. http://hdl.handle.net/10622/QK8VRF (accessed: 2019-o8-26), IISH Dataverse, $\mathrm{V}$.

${ }_{18} / /$ www.ilo.org/stat/Publications/octoberinquiry/lang--en/index.htm (accessed: 2019-08-26). 
However, in the first years after the start of the October Inquiry, the ILO was able to publish labour statistics data only on 15 countries. Unfortunately, Lithuania (which joined the League of Nations and the ILO in 1921) ${ }^{19}$ was one of the member countries which were not able to answer ILO data requests, or adapt its practices of data collection to the guidelines from Geneva. So we can find in the ILO's publications only information about the mean wages of skilled and unskilled male and female industrial workers in this country for the period 1930 to 1938 , which was also published in the Statistical Yearbook of Lithuania. ILO publications also do not provide data about retail prices in Lithuania, although this data has been published by the Lithuanian national statistics office. These data gaps explain why de Zwart provides no real wage data estimates about interwar Lithuania in his data collection.

Table 2 presents data on wages and prices in Lithuania which we were able to collect for the application of Allen's methods. We consciously excluded from the analysis the 1915 to 1922 period, because of the absence of data or their unreliability under conditions of inflation, which was halted by the introduction of the Lithuanian national currency the litas in October 1922. Applying Allen's template, we limited our analysis to Kaunas, interwar Lithuania's provisional capital. This limitation enhances the comparability of our findings with those of other researchers, and may improve the reliability of our data, as they were collected most systematically in the central cities.

${ }^{19}$ K. Strimaitis, Tarptautine darbo organizacija (Kaunas, 1936). 
Table 2. Prices of consumer goods from de Zwart's and Allen's subsistence baskets and hourly wages of unskilled and skilled construction workers, Kaunas 1913 , and 1923 to $1940^{20}$

\begin{tabular}{|c|c|c|c|c|c|c|c|c|}
\hline \multicolumn{9}{|c|}{ Prices and wages per unit (Kaunas) } \\
\hline $\begin{array}{l}\text { Commodities and } \\
\text { wages }\end{array}$ & units & 1913 & 1923 & 1924 & 1925 & 1926 & 1927 & 1928 \\
\hline Rye bread & $\mathrm{kg}$ & 0.37 & 0.38 & 0.5 & 0.5 & 0.55 & 0.6 & 0.6 \\
\hline Peas & $\mathrm{kg}$ & 0.45 & 0.37 & 0.48 & 0.50 & 0.47 & 0.48 & 0.58 \\
\hline Potatoes & $\mathrm{kg}$ & 0.11 & 0.11 & 0.13 & 0.12 & 0.09 & 0.12 & 0.15 \\
\hline Meat (pork) & $\mathrm{kg}$ & 2.05 & $3.5^{\circ}$ & 2.93 & 3.58 & 3.20 & 3.10 & 3.15 \\
\hline Butter & $\mathrm{kg}$ & $5 \cdot 35$ & 8.75 & 6.29 & 7.40 & 6.30 & 6.45 & 6.50 \\
\hline Soap & $\mathrm{kg}$ & 1.60 & 1.60 & 2.34 & 2.27 & 2.20 & 2.30 & 2.25 \\
\hline Cloth (cotton) & $\mathrm{m}$ & 1.75 & 3.00 & 2.97 & 3.41 & 3.95 & 2.95 & 2.80 \\
\hline Lighting (kerosene) & litre & 0.71 & 0.45 & 0.58 & 0.58 & $0.5^{2}$ & 0.55 & 0.55 \\
\hline Fuel & $\mathrm{mBTU}$ & 1.71 & 2.32 & 2.34 & 2.59 & 2.31 & 2.24 & 2.05 \\
\hline Housing & $3 \mathrm{~m}^{2}$ & 15.0 & 15.0 & 15.0 & 15.0 & 15.0 & 15.0 & 15.0 \\
\hline $\begin{array}{l}\text { Construction } \\
\text { labourers wages }\end{array}$ & 1 hour & 0.62 & nd & nd & nd & nd & 0.74 & 0.64 \\
\hline $\begin{array}{l}\text { Construction craftsmen } \\
\text { (carpenter) wages }\end{array}$ & 1 hour & 0.93 & 1.0 & nd & nd & nd & nd & nd \\
\hline $\begin{array}{l}\text { Unskilled industry } \\
\text { worker mean wages }\end{array}$ & 1 hour & nd & nd & nd & nd & nd & nd & nd \\
\hline $\begin{array}{l}\text { Skilled industry } \\
\text { worker mean wages }\end{array}$ & 1 hour & nd & nd & nd & nd & nd & nd & nd \\
\hline
\end{tabular}

${ }^{20}$ Data sources on prices in Kaunas in 1913: Ведомость о справочных ценах на припасы и материалы употребляемые в Ковенской губернской тюрьме за октябрь 1913 года, Kauno regioninis valstybės archyvas (Kaunas Regional State Archives, KRVA) col. I-61, inv. 3, file. 2194, p. 662-663v; 1913 Сведения Ковенской городской управы о справочных ценах на продукты первой необходимости, существующих в гор. Ковне в августе 1913 г., KRVA, col. I-61, inv. 3, file. 2194, p. 76; 1913 Ceny na predmety material'nogo kataloga na 1913 g., KRVA, col. I-61, inv. 3, file. 2194, p. 89; 1913 Список предметам, потребным к заподряжению для Ковенских городских больниц и богаделен в течении 1913 года, по коим необходимы от Ковенской городской управы справочные цены за январь, февраль, март, апрель и май месяцы 1913 года, KRVA, col. I-61, inv. 3, file. 2194, p. 242; 1913 Справочные цены на канцелярские и другие материалы, а также работы, существующие в г. Ковне с 1 июля 1913 г., KRVA, col. I-61, inv. 3, file. 2194, p. 378v; 1913 Ведомость о справочных ценах на припасы и материалы употребляемые в Ковенской губернской тюрьме за ноябрь 1913 года, KRVA,col. I-61, inv. 3, file. 2194, p. 492v. On prices in 1923-1940: Lietuvos ūkis, 10 (1923), p. 57; Lietuvos ükininkas, 36 (1925), p. 10; 19241925 Lietuvos ūkininkas, 36 (1925), p. 10; 19241120 Krašto apsaugos ministerio ìsakymas No 122 (Kaunas, 1924), p. 1; 19271231 Krašto apsaugos ministerio isakymas No 112 (Kaunas, 1927), p. 1; 1928 o2 og I sakymas kariuomenei No 14 (Kaunas, 1928), p. 1; 19290514 Isakymas kariuomenei No 40 (Kaunas, 1929 ), p. 1; 19300107 Isakymas kariuomenei No 4 (Kaunas, 1930), p. 1; 1931 o2 o7 İsakymas kariuomenei No 11 (Kaunas, 1931), p. 1; 19320227 Isakymas kariuomenei No 17 (Kaunas, 1932), p. 1; 19330218 İsakymas kariuomenei No 11 (Kaunas, 1933), p. 1. 19340220 İsakymas kariuomenei No 15 


\begin{tabular}{|c|c|c|c|c|c|c|c|c|c|c|c|}
\hline \multicolumn{12}{|c|}{ Prices and wages per unit (Kaunas) } \\
\hline 1929 & $193 \circ$ & 1931 & $193^{2}$ & 1933 & 1934 & 1935 & 1936 & 1937 & 1938 & 1939 & 1940 \\
\hline o. 6 & 0.4 & 0.34 & 0.46 & 0.3 & 0.22 & 0.2 & 0.23 & 0.27 & 0.24 & 0.25 & 0.34 \\
\hline 0.51 & 0.28 & 0.28 & 0.27 & 0.23 & 0.28 & 0.27 & 0.27 & 0.27 & 0.27 & 0.28 & 0.46 \\
\hline 0.16 & 0.06 & 0.08 & 0.06 & 0.06 & 0.07 & 0.04 & o.o6 & 0.07 & 0.05 & 0.07 & 0.09 \\
\hline 3.20 & 3.05 & 2.15 & 1.45 & 1.30 & 1.40 & 1.00 & 1.30 & 1.60 & 1.65 & $1.5^{\circ}$ & 2.02 \\
\hline 6.85 & 6.00 & 5.05 & 4.10 & 3.30 & 3.20 & 2.85 & 3.05 & 3.35 & $3.5^{\circ}$ & 3.60 & $3 \cdot 35$ \\
\hline 2.35 & 2.30 & 2.20 & 1.95 & 1.90 & 1.90 & 1.55 & $1.5^{\circ}$ & 1.65 & 1.70 & 1.80 & 2.71 \\
\hline 2.65 & 2.55 & 2.25 & 1.95 & $1.5^{\circ}$ & $\begin{array}{l}1.50 \\
0\end{array}$ & $\begin{array}{l}1.65 \\
\end{array}$ & 1.50 & 1.40 & 1,47 & 1.53 & 2.11 \\
\hline 0.55 & 0.55 & 0.40 & 0.45 & 0.40 & 0.34 & 0.34 & 0.32 & 0.35 & 0.35 & 0.42 & 0.59 \\
\hline 2.01 & 2.02 & 1.94 & 1.56 & 1.32 & 1.78 & 2.43 & 2.55 & 2.80 & 2.89 & 3.11 & 2.08 \\
\hline 15.0 & 15.0 & 18.0 & 16.0 & 14.8 & 14.6 & 13.0 & 12.3 & 12.9 & 12.8 & 13.8 & 13.6 \\
\hline 0.72 & nd & nd & 0.64 & 0.55 & $\begin{array}{lll}0.45 \\
\end{array}$ & 0.43 & 0.60 & 0.55 & $\begin{array}{l}0,59 \\
\end{array}$ & nd & nd \\
\hline nd & 1.44 & 1.49 & 1.12 & 0.94 & 0.85 & 0.91 & 1.01 & 1.02 & 0.89 & 0.90 & nd \\
\hline nd & 0.85 & 0.82 & 0.78 & 0.69 & 0.66 & 0.65 & 0.64 & 0.69 & o.69 & 0.72 & nd \\
\hline nd & 1.65 & 1.63 & 1.44 & 1.28 & 1.21 & 1.19 & 1.19 & 1.21 & 1.22 & 1.19 & nd \\
\hline
\end{tabular}

(Kaunas, 1934), p. 1; 19350129 Isakymas kariuomenei No 10 (Kaunas, 1935), p. 1; 19360204 Isakymas kariuomenei No 9 (Kaunas, 1936), p. 5; 1937 o2 o6 İsakymas kariuomenei No 13 (Kaunas, 1937), p. 1; 1938 o1 11 İsakymas kariuomenei No 3 (Kaunas, 1938), p. 1; 1939 o1 31 İsakymas kariuomenei No 8 (Kaunas, 1939), p. 1; 1940 or 24 İsakymas kariuomenei No 7 (Kaunas, 1940), p. 1; Vidutinès prekių kainos Lietuvoje 1923 m. spalių mèn. ir ju indeksai, Statistikos biuletenis 1 (1923) (Kaunas, 1923), p. 8; Kainos Lietuvoje prieš karą ir dabartiniu laiku, Statistikos biuletenis 2 (1923) (Kaunas, 1923), p. 9; Vidutinès prekių kainos Lietuvoje 1924 m. spalių mèn. ir jų indeksai, Statistikos biuletenis, 11 (1924), (Kaunas, 1924), pp. 13-14; Vidutinès prekių kainos Lietuvoje 1925 m. spaliu m. ir jų indeksai, Statistikos biuletenis, 11 (1925) (Kaunas, 1925), pp. 22-23; Vidutinès prekių kainos Lietuvoje 1926 m. spalių mèn. ir jų indeksai, Statistikos biuletenis, 11 (1926) (Kaunas, 1926), pp. 30-31; Vidutinès prekių kainos Lietuvoje 1927 m. spalių m. ir ju indeksai, Statistikos biuletenis, 11 (1927) (Kaunas, 1927), pp. 30-31; Prekių kainos (vidutinès) Lietuvoje $1928 \mathrm{~m}$. spalių mèn. ir jų indeksai, Statistikos biuletenis, 11 (1928) (Kaunas, 1928), pp. 22-23; Prekių kainos (vidutinès) Lietuvoje 1929 m. spalių mèn. ir jų indeksai, Statistikos biuletenis, 11 (1929) (Kaunas, 1929), pp. 22-23; Prekių kainos (vidutinès) Lietuvoje 1930 m. spalių mėn. ir jų indeksai, Statistikos biuletenis, 12 (1930) (Kaunas, 1930), p. 14-15; Prekių kainos (vidutinės) Lietuvoje $1931 \mathrm{~m}$. spaliu mèn. ir jų indeksai, Statistikos biuletenis, 11 (1931) (Kaunas, 1931), pp. 24-25; Prekių kainos (vidutinės) Lietuvoje 1932 m. spalių mèn. ir jų indeksai, Statistikos biuletenis, 11 (1932) (Kaunas, 1932), pp. 24-25; Prekių kainos (vidutinės) Lietuvoje 1933 m. spalių mėn. ir jų 


\section{Findings}

Table 3 presents findings of the calculation of the annual cost of de Zwart's northeast European and Allen's Russian subsistence basket in 1913, and 1923 to 1940, in current prices, using data displayed in Table 2. For 1913, we used prices and wages in litas, converting Russian roubles to litas according to gold parity $(1$ rouble $=5.15 \mathrm{Lt}$ ). Table 4 presents our findings about the wages of unskilled construction workers (in 1913, 1927 to 1929, and 1932 to 1938) and skilled construction workers (for 1913, 1923, and 1930 to 1939) in subsistence and welfare ratios, using the price of de Zwart's northeast European subsistence basket. Table 5 presents the findings on real wages for the same categories of wage workers in subsistence and welfare ratios, derived using Allen's Russian subsistence basket.

indeksai, in Statistikos biuletenis, 11 (1933) (Kaunas, 1933), pp. 21-22, 23; Prekių kainos (vidutinės) Lietuvoje 1934 m. spalių mėn. ir jų indeksai, Statistikos biuletenis, 11 (1934) (Kaunas, 1934), pp. 21-22; Prekių kainos (vidutinès) Lietuvoje 1935 m. spalių mèn. ir jų indeksai, Statistikos biuletenis, 11 (1935) (Kaunas, 1935), pp. 28-29; Prekių kainos (vidutinès) Lietuvoje 1936 m. spalių mèn. ir jų indeksai, Statistikos biuletenis, 11 (1936) (Kaunas, 1936), pp. 28-29; Prekių kainos (vidutinės) Lietuvoje 1937 m. spalių mèn. ir jų indeksai, Statistikos biuletenis, 11 (1937) (Kaunas, 1937), pp. 29-3o; Prekių kainos (vidutinès) Lietuvoje 1938 m. spalių mẻn. ir jų indeksai, Statistikos biuletenis, 11 (1938) (Kaunas, 1938), pp. 26-27; Prekių kainos (vidutinės) Lietuvoje 1939 m. spalių mèn. ir jų indeksai, Statistikos biuletenis, 11-12 (1939) (Kaunas, 1939), pp. 435-436, 438; Prekiu kainos (vidutinès) Lietuvoje 1940 m. spalių mėn. ir jų indeksai, Statistikos biuletenis, 10 (1940) (Kaunas, 1940), pp. 157-159, 16o; Lietuvos statistikos metraštis, 3 (1929-1930) (Kaunas, 1931), pp. 372-389; Lietuvos statistikos metraštis, 4 (1931) (Kaunas, 1932), pp. 48-251; Lietuvos statistikos metraštis, 5 (1932) (Kaunas, 1933), pp. 108-11; Lietuvos statistikos metraštis, 6 (1933) (Kaunas, 1934), pp. 112-115; Lietuvos statistikos metraštis, 7 (1934) (Kaunas, 1935), pp. 114-117; Lietuvos statistikos metraštis, 8 (1935) (Kaunas, 1936), pp. 122-125; Lietuvos statistikos metraštis, 9 (1936) (Kaunas, 1937), pp. 120-123; Lietuvos statistikos metraštis, 10 (1937) (Kaunas, 1938), pp. 294-299; Lietuvos statistikos metraštis, 11 (1938) (Kaunas, 1939), pp. 284-289; Lietuvos statistikos metraštis 12 (1939) (Vilnius, 1940), pp. 304-309. On wages in Kaunas 1913: Копия ведомости о справочных ценах на инструменты, приборы и материалы с доставкой их, а также плату мастеровым и рабочим по строительной части по гор. Ковна, открытых по январскую треть 1913 года, KRVA, col. I-61, inv. 3, file. 2194, p. 37-37v; Копия ведомости о справочных ценах на инструменты, приборы и материалы с доставкою их, а также плату мастеровым и рабочим по строительной части по гор. Ковна на сентябрьскую треть 1913 года, KRVA,col. I-61, inv. 3, file. 2194, p. 637-37V; on the wages of construction labourer wages in 1927-1929 and 1932-1938: Kauno miesto statistikos metraštis, 5 (1938) (Kaunas, 1939), p. 48; unskilled and skilled industrial workers, carpenters' wages in 1930-1939: Lietuvos statistikos metraštis (1939) (Vilnius, 1940), pp. 188-189. 
Despite the many gaps, our findings allow us to draw important conclusions about the overall dynamics of real wage changes during the interwar period. Firstly, we should note the difference in the patterns of change of nominal and real wages. The nominal wages of both skilled and unskilled construction workers were highest at the end of the first interwar decade, surpassing its 1913 levels (155 Lt per month for carpenters, 103 Lt for labourers) by 6०\% for carpenters in 1931 (248 Lt), and by 16\% in 1929 (120 Lt) for labourers (zimagoras). As could be expected, they dropped sharply during the Great Depression in the first half of the 1930s, contracting in 1934 for carpenters by 43\% (to $142 \mathrm{Lt}$ ), and in 1935 by $41 \%$ (to $71 \mathrm{Lt}$ ), in comparison with 1931 and 1929 respectively. In 1938, nominal wages (148 Lt per month for craftsmen, $99 \mathrm{Lt}$ for zimagoras) were still below the 1913 level.

However, measuring changes in the purchasing power of wages with de Zwart's basket, we observe a completely different picture. In 1913, the price of de Zwart's subsistence basket was 111.36 litas, while in 1924 it was nearly two times higher, meaning the corresponding rise in the cost of living. Its price gradually decreased in the next few years, dropping sharply in the years of the depression. In 1935, its price was only 67.69 litas, or $60.8 \%$ of its pre-First World War value. By 1938, the price of the subsistence basket (79.77 Lt) was still significantly below the 1913 level. Because the food price increase during the first interwar decade in comparison with 1913 was higher than the increase in nominal wages, and the food price decrease was greater than the contraction of nominal wages during the second decade, the real wages of unskilled construction workers in 1929 were still lower than in 1913, but palpably surpassed the prewar level in 1938. In 1913, a zimagoras could buy for his annual wage 11.14 of Zwart's subsistence baskets, 8.69 in 1929, and 14.82 in 1938. Importantly, except for 1932, the real wages of unskilled workers during the depression did not drop below the 1913 level.

The dynamics of the real wages of construction craftsmen displays a somewhat different picture. Not only the nominal, but also the real wages of Kaunas carpenters surpassed the 1913 level (16.7 subsistence ratios) before the Great Depression in the 1930s, hitting the level of 28.55 subsistence ratios in 1931. After contracting 
Table 3. The annual cost of de Zwart's northeast European and Allen's Russian subsistence baskets in Kaunas 1913, and 1923 to 1940. For data sources, see references to Table 2 .

\begin{tabular}{|l|l|l|l|l|l|l|l|l}
1913 & 1923 & 1924 & 1925 & 1926 & 1927 & 1928 & 1929 & 1930
\end{tabular}

Annual cost of de Zwart's East European subsistence basket

(in litas, current prices)

\begin{tabular}{l|l|l|l|l|l|l|l|l|l|l|l} 
One adult & 111.36 & 131.00 & 217.95 & 154.41 & 158.79 & 165.03 & 166.24 & 165.62 & 122.09 \\
\hdashline Family & 350.78 & 412.65 & 686.55 & 486.39 & 500.18 & 519.84 & 523.67 & 521.69 & 384.58 \\
\hline
\end{tabular}

Annual cost of Allen's Russian subsistence basket (in litas, current prices)

\begin{tabular}{l|l|l|l|l|l|l|l|l|l|l|l|l|l|l|l|l} 
One adult & 278.82 & 365.98 & 498.53 & 424.04 & 454.28 & 416.11 & 407.71 & 401.26 & 334.34
\end{tabular}

\begin{tabular}{ll|l|l|l|l|l|l|l|l|l|l|l|l|l|l|l|l|l} 
Family & 851.47 & 1112.95 & 1510.60 & 1287.12 & 1377.83 & 1263.33 & 1238.13 & 1218.78 & 1018.02
\end{tabular}

Table 4. Real wages of Kaunas construction labourers and craftsmen in 1913 to 1940 in subsistence and welfare ratios, calculated using de Zwart's northeast European subsistence basket. For data, see Table 2 and 3 .

\begin{tabular}{|c|c|c|c|c|c|c|c|c|}
\hline & 1913 & 1923 & 1924 & 1925 & 1926 & 1927 & 1928 & 1929 \\
\hline & \multicolumn{8}{|c|}{ Construction labourers (zimagoras) } \\
\hline $\begin{array}{l}\text { Mean nominal } \\
\text { annual wage in } \\
\text { litas }\end{array}$ & 1240.0 & nd & nd & nd & nd & 1480.0 & 1277.5 & 1440.0 \\
\hline $\begin{array}{l}\text { Mean real } \\
\text { annual wage } \\
\text { in subsistence } \\
\text { ratios }\end{array}$ & 11.14 & nd & nd & nd & nd & 8.97 & 7.68 & 8.69 \\
\hline \multirow{2}{*}{$\begin{array}{l}\text { Family welfare } \\
\text { ratio }\end{array}$} & $3 \cdot 54$ & nd & nd & nd & nd & 2.85 & 2.44 & 2.76 \\
\hline & \multicolumn{8}{|c|}{ Construction craftsmen (stalius, carpenter) } \\
\hline $\begin{array}{l}\text { Mean nominal } \\
\text { annual wage in } \\
\text { litas }\end{array}$ & 186o.o & 2000.0 & nd & nd & nd & nd & nd & nd \\
\hline $\begin{array}{l}\text { Mean real } \\
\text { annual wage } \\
\text { in subsistence } \\
\text { ratios }\end{array}$ & 16.70 & 15.27 & nd & nd & nd & nd & nd & nd \\
\hline $\begin{array}{l}\text { Family welfare } \\
\text { ratio }\end{array}$ & $5 \cdot 30$ & 4.85 & nd & nd & nd & nd & nd & nd \\
\hline
\end{tabular}




\begin{tabular}{l|l|l|l|l|l|l|l|l|l}
1931 & 1932 & 1933 & 1934 & 1935 & 1936 & 1937 & 1938 & 1939 & 1940
\end{tabular}

Annual cost of de Zwart's East European subsistence basket

(in litas, current prices)

\begin{tabular}{l|l|l|l|l|l|l|l|l|l}
\hline 104.19 & 118.16 & 83.77 & 71.77 & 67.69 & 74.32 & 83.98 & 79.77 & 82.75 & 103.46 \\
\hline 328.19 & 372.21 & 263.88 & 226.07 & 213.22 & 234.11 & 264.53 & 251.27 & 260.67 & 325.91 \\
\hline
\end{tabular}

Annual cost of Allen's Russian subsistence basket (in litas, current prices)

\begin{tabular}{|l|l|l|l|l|l|l|l|l|l}
294.15 & 297.31 & 222.21 & 205.40 & 209.16 & 212.48 & 225.37 & 221.75 & 233.70 & 284.26 \\
\hline 900.46 & 907.94 & 681.43 & 630.81 & 640.48 & 649.73 & 689.00 & 678.06 & 714.90 & 866.37 \\
\hline
\end{tabular}

\begin{tabular}{|c|c|c|c|c|c|c|c|c|c|}
\hline $193 \circ$ & 1931 & $193^{2}$ & 1933 & 1934 & 1935 & 1936 & 1937 & 1938 & 1939 \\
\hline \multicolumn{10}{|c|}{ Construction labourers (zimagoras) } \\
\hline nd & nd & 1272.5 & $1105 \cdot 0$ & $892.5^{\circ}$ & 855.00 & 1200.0 & 1107.5 & 1182.5 & nd \\
\hline nd & nd & 10.77 & 13.19 & 12.44 & 12.63 & 16.15 & 13.19 & $\begin{array}{l}14.82 \\
\end{array}$ & nd \\
\hline nd & nd & 3.42 & 4.19 & 3.95 & 4.01 & 5.13 & 4.19 & $4 \cdot 71$ & nd \\
\hline
\end{tabular}

Construction craftsmen (stalius, carpenter)

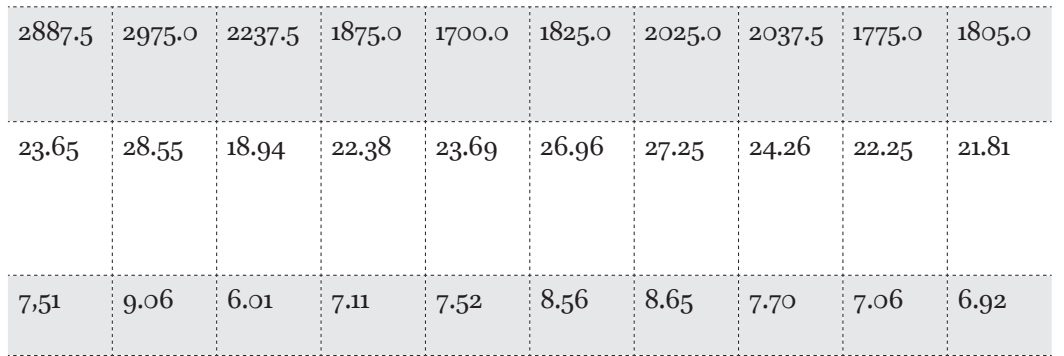


Table 5. Real wages of Kaunas construction labourers and craftsmen in 1913 to 1940 in subsistence and welfare ratios, calculated using Allen's Russian subsistence basket. For data, see Table 2 and 3 .

\begin{tabular}{|c|c|c|c|c|c|c|c|c|}
\hline & 1913 & 1923 & 1924 & 1925 & 1926 & 1927 & 1928 & 1929 \\
\hline & \multicolumn{8}{|c|}{ Construction labourers (zimagoras) } \\
\hline $\begin{array}{l}\text { Mean nominal } \\
\text { annual wage in } \\
\text { litas }\end{array}$ & 1240.0 & nd & nd & nd & nd & 1480.0 & $1277 \cdot 5$ & 1440.0 \\
\hline $\begin{array}{l}\text { Mean real } \\
\text { annual wage } \\
\text { in subsistence } \\
\text { ratios }\end{array}$ & 4.45 & nd & nd & nd & nd & 3.56 & 3.13 & 3.59 \\
\hline \multirow{2}{*}{$\begin{array}{l}\text { Family welfare } \\
\text { ratio }\end{array}$} & 1.46 & nd & nd & nd & nd & 1.17 & 1.03 & 1.18 \\
\hline & \multicolumn{8}{|c|}{ Construction craftsmen (stalius, carpenter) } \\
\hline $\begin{array}{l}\text { Mean nominal } \\
\text { annual wage in } \\
\text { litas }\end{array}$ & 1860.0 & 2000.0 & nd & nd & nd & nd & nd & nd \\
\hline $\begin{array}{l}\text { Mean real } \\
\text { annual wage } \\
\text { in subsistence } \\
\text { ratios }\end{array}$ & 6.67 & 5.46 & nd & nd & nd & nd & nd & nd \\
\hline $\begin{array}{l}\text { Family welfare } \\
\text { ratio }\end{array}$ & 2.18 & 1.80 & nd & nd & nd & nd & nd & nd \\
\hline
\end{tabular}

by $33 \%$ (to 18.94) during a single year, they did not recover to this top pre-crisis level until the beginning of the Second World War, but with 22.25 subsistence ratios markedly surpassed the 1913 real wages level.

Describing the standard of living of workers in welfare ratios, we get the same picture in relative terms. The nominal cost of subsistence of a four-person family on the absolute poverty level was 351 litas in 1913, nearly doubling (to $687 \mathrm{Lt}$ ) in 1924, and then dropping to 213 litas in 1935, which was $31 \%$ of the 1924 and $61 \%$ of the 1913 level. In 1938, it was 251 litas, or $71.5 \%$ of the 1913 level. With these prices of the family subsistence basket, a zimagoras could maintain his family 3.54 times above the absolute poverty level in 1913, and 4.71 times in 1938. In the years in between with available data, the year 1928 (known for widespread crop failure) was the hardest, with the welfare ratio of a labourer's family fall- 


\begin{tabular}{|c|c|c|c|c|c|c|c|c|c|}
\hline 1930 & 1931 & 1932 & 1933 & 1934 & 1935 & 1936 & 1937 & 1938 & 1939 \\
\hline \multicolumn{10}{|c|}{ Construction labourers (zimagoras) } \\
\hline nd & nd & 1272.5 & 1105.0 & 892.50 & 855.00 & 1200.0 & 1107.5 & 1182.5 & nd \\
\hline nd & nd & 4.28 & $4 \cdot 97$ & $4 \cdot 35$ & 4.09 & 5.65 & 4.91 & $5 \cdot 33$ & nd \\
\hline nd & nd & 1.40 & 1.62 & 1.41 & 1.33 & 1.85 & 1.61 & 1.74 & nd \\
\hline \multicolumn{10}{|c|}{ Construction craftsmen (stalius, carpenter) } \\
\hline $2887 \cdot 5$ & 2975.0 & $2237 \cdot 5$ & 1875.0 & 1700.0 & 1825.0 & 2025.0 & $2037 \cdot 5$ & $1775 \cdot 0$ & 1805.0 \\
\hline 8.64 & 10.11 & $7 \cdot 53$ & 8.44 & 8.28 & 8.73 & $9 \cdot 53$ & 9.04 & 8.00 & $7 \cdot 72$ \\
\hline 2.84 & $3 \cdot 30$ & 2.46 & 2.75 & 2.69 & 2.85 & 3.12 & 2.96 & 2.62 & $2.5^{2}$ \\
\hline
\end{tabular}

ing to 2.44 that year. None of the years of the Great Depression (with data available) was so severe. The year 1932 was the worst, when the welfare ratio was 3.42. The families of skilled workers in all years with available data lived rather high above the absolute poverty level. By 1923, their welfare ratio (4.85) was only slightly below the 1913 level $(5 \cdot 3)$, increasing to 9.06 by 1931, falling to 6.01 the next year, and recovering to 7.06 in 1938 .

However, the description of the minimal survival needs provided by de Zwart's basket is completely unrealistic for the Lithuanian conditions. The application of Allen's Russian subsistence basket provides a picture which may be much closer to the reality. According to this measure (see Table 5), in 1913 a construction labourer (zimagoras) could buy for his annual earnings $(1,240 \mathrm{Lt})$ only 4.45 annual subsistence baskets. Despite the higher nominal wage, its purchasing power decreased in 1928 to 3.13 subsistence 
ratios. During the depression (in 1932 to 1935), it was almost at the pre-First World War level, surpassing it slightly in the period 1936 to 1938 with a 5.33 subsistence ratio in 1938 . However, these wages were only slightly more than necessary for a zimagoras' family to survive, as the welfare ratio of a construction labourer's wage was 1.46 in 1913, and 1.74 in 1938. It did sink to 1.03 in 1928, which meant life in absolute poverty if no other family members were employed.

The picture of the standard of living of skilled construction workers is much brighter. In 1913, Kaunas carpenters could afford to buy 6.67 Russian subsistence baskets (see Table 5). The purchasing power of their wages reached its interwar maximum in 1931, when they could buy 10.11 baskets. The next year, when their real wages plummetted to their depression minimum of 7.53 baskets, they still remained higher than before the First World War. Their wages recovered in 1936 to 1939, allowing them to buy eight subsistence baskets in 1938. These wages enabled construction workers to maintain their families at a level of 2.5 to three WR (see Table 5 ).

Applying Allen's Russian version of the subsistence basket for cross-national comparisons, we find that on the eve of the First World War, the standard of living of Lithuanian workers was no worse than that of their Russian counterparts in Moscow and St Petersburg, where the WR of construction labourer's family households was above 1.3 times above the subsistence level, while that of carpenters approached two. ${ }^{21}$ It was clearly higher than the standard of living of Russian workers in the Russian provincial town of Kursk, where the WR of carpenter families was only 1.2 times above the absolute poverty level, and that of labourers' families was only 0.9 of it. ${ }^{22}$ This finding supports the view that Lithuania was not a poor peripheral area of the Russian Empire, but one of its more economically advanced regions. ${ }^{23}$

According to Khaustova and Allen's findings, the wages of workers in Russia improved in the 1920s, with real wages of

${ }^{21}$ R.C. Allen, E. Khaustova, 'Russian Real Wages Before and After 1917: in Global Perspective', pp. 10, 26-27.

${ }^{22}$ Ibidem, p. 28.

${ }^{23}$ G. Vaskela, Tautiniai aspektai Lietuvos ūkio politikoje 1919-1940 metais (Vilnius, 2014), pp. 70-74. 
carpenters approaching three welfare ratios (WR) by 1929, and that of construction labourers 1.7 (WR). At that time, unskilled workers in Russia could consume more than their counterparts the zimagoras in Kaunas. However, during the next decade, the trend was the reverse. By 1933, the welfare ratio of carpenters in Moscow had fallen to one, while that of construction labourers had fallen to $0.75 .{ }^{24}$ This was the effect of Stalin's drive to industrialise Russia. 'Lenin had given the Russian worker what he could in view of the country's underdevelopment. Stalin took from them what was necessary in order for Russia to catch up to the West.' ${ }^{25}$ Very differently, the standard of living of workers in Lithuania improved, despite the economic crisis, surpassing the 1913 level both for skilled and unskilled construction workers (see Table 5).

Of course, Lithuanian wages were not impressive compared with those in the most advanced countries of the world. In Boston (USA), the welfare ratio of a construction labourer's family was four times above the subsistence level by 1914, approaching eight by 1938; while the standard of living of their counterparts in Manchester did not change much during the period 1913 to 1938 , remaing at the level of three to four WR. ${ }^{26}$ Importantly, it was not significantly affected during the worldwide economic depression of 1929 to 1933, reducing the purchasing power of unskilled workers by only one WR. The welfare ratio of skilled construction workers was six times above the subsistence level in Boston, and four times in Manchester by 1914. Then wages increased to 12 WR in the USA, but only to five WR in the UK, by 1929. However, the wages of British workers were only slightly affected by the Great Depression during the next few years, while those of Americans decreased to eight WR. While the Stalinist policy of industrialisation did drive the real wages of Russian workers below the level of their class peers in Bombay in India (around 1.5 to two WR in the 1930s), the real wages of Lithuania's skilled workers improved modestly but noticeably in the period 1913 to 1938 .

${ }^{24}$ R.C. Allen, E. Khaustova, 'Russian Real Wages Before and After 1917: in Global Perspective', p. 26.

${ }^{25}$ Ibidem, p. 12.

${ }^{26}$ Ibidem, p. 3 o. 
Table 6. Wages of construction labourers in capital cities of European countries, $1913-1939 \cdot{ }^{27}$

\begin{tabular}{|c|c|c|c|c|c|c|c|c|c|c|}
\hline Country & 1913 & 1914 & 1920 & 1921 & 1922 & 1923 & 1924 & 1925 & 1926 & 1927 \\
\hline Austria & nd & nd & 2.24 & 21.59 & 14.43 & $\begin{array}{l}14.69 \\
\end{array}$ & 19.15 & 17.42 & $\begin{array}{l}16.37 \\
\end{array}$ & 18.74 \\
\hline Denmark & nd & 16.00 & 51.70 & 50.5 & 51.06 & $\begin{array}{l}50.09 \\
\end{array}$ & 49.81 & 49.83 & 51.27 & 43.02 \\
\hline Estonia & nd & nd & nd & nd & nd & $\begin{array}{ll}\text { nd } \\
\text { a }\end{array}$ & nd & $\begin{array}{l}10.27 \\
\end{array}$ & nd & nd \\
\hline Finland & nd & nd & nd & nd & nd & nd & nd & nd & nd & nd \\
\hline France & nd & nd & nd & 9.46 & nd & nd & 7.92 & nd & nd & nd \\
\hline Germany & 28.59 & nd & nd & nd & nd & nd & $\begin{array}{l}20.80 \\
\end{array}$ & 21.92 & 20.56 & 21.30 \\
\hline Hungary & nd & nd & nd & nd & nd & nd & nd & nd & nd & nd \\
\hline Italy & 9.44 & 9.75 & nd & nd & nd & nd & 12.1 & 10.83 & 11.98 & 14.91 \\
\hline Latvia & nd & nd & nd & nd & nd & nd & nd & 8.18 & 7.61 & 10.14 \\
\hline Lithuania & 11.14 & nd & nd & nd & nd & nd & nd & nd & nd & 8.97 \\
\hline $\begin{array}{l}\text { Nether- } \\
\text { lands }\end{array}$ & nd & nd & nd & nd & nd & nd & nd & 28.93 & 28.89 & 33.65 \\
\hline Norway & nd & 27.06 & 29.48 & 31.80 & 28.45 & 28.86 & 30.75 & 32.57 & $\begin{array}{l}32.01 \\
\end{array}$ & nd \\
\hline Turkey & 4.88 & nd & nd & nd & nd & nd & nd & nd & nd & nd \\
\hline Poland & 24.62 & nd & nd & nd & nd & nd & nd & $9 \cdot 92$ & 6.49 & 8.64 \\
\hline Portugal & nd & nd & nd & nd & nd & nd & nd & 8.48 & $9 \cdot 35$ & 5.76 \\
\hline Romania & nd & nd & nd & nd & nd & nd & nd & nd & nd & nd \\
\hline Spain & 22.95 & nd & nd & nd & nd & 17.84 & 14.38 & 13.83 & nd & 11.91 \\
\hline Sweden & nd & 24.26 & 28,95 & nd & 28.68 & 31.01 & 31.62 & 31.00 & 29.53 & 29.19 \\
\hline $\begin{array}{l}\text { Switzer- } \\
\text { land }\end{array}$ & 16.78 & nd & nd & 19.32 & 21.36 & 20.55 & nd & nd & nd & nd \\
\hline $\begin{array}{l}\text { United } \\
\text { Kingdom }\end{array}$ & 29.49 & 20.88 & 27.73 & 32.4 & 26.64 & 25.45 & 26.27 & 29.07 & 31.32 & 31.59 \\
\hline $\begin{array}{l}\text { United } \\
\text { States }\end{array}$ & nd & nd & nd & nd & nd & nd & nd & 68.48 & 70.66 & 80.55 \\
\hline Yugoslavia & $\mathrm{Nd}$ & nd & nd & nd & nd & nd & nd & nd & nd & nd \\
\hline
\end{tabular}

${ }^{27}$ Own calculation (for Lithuania) and P. de Zwart, B. van Leeuwen, J. van Leeuwen-Li, 'Labourers Real Wage' (2015), http://hdl.handle.net/10622/QK8VRF (accessed: 2019-08-26), IISH Dataverse, V1. 


\begin{tabular}{|c|c|c|c|c|c|c|c|c|c|c|c|}
\hline 1928 & 1929 & 1930 & 1931 & $193^{2}$ & 1933 & 1934 & 1935 & 1936 & 1937 & 1938 & 1939 \\
\hline 19.14 & 16.07 & 15.85 & 18.6 & 16.25 & 18.19 & 17.06 & 14.5 & $15 \cdot 32$ & 15.46 & nd & nd \\
\hline 48.63 & 44.04 & 44.21 & 57.77 & 56.77 & 53.81 & 53.59 & $5^{2.47}$ & 48.56 & 29.02 & 45.21 & 35.96 \\
\hline nd & 8.80 & 6.83 & 11.79 & 9.62 & 7.82 & 9.58 & 12.17 & 10.48 & 10.15 & 9.66 & 9.90 \\
\hline nd & nd & nd & nd & nd & nd & nd & nd & nd & nd & nd & 21.34 \\
\hline 16.23 & $17.5^{2}$ & 14.26 & 17.72 & 19.88 & 24.07 & 20.27 & 19.34 & 19.02 & 20.28 & 18.41 & nd \\
\hline $25 \cdot 33$ & nd & 27.2 & 28.51 & 25.14 & nd & nd & nd & nd & nd & nd & nd \\
\hline nd & nd & nd & nd & 8.34 & 9.83 & 8.56 & 8.93 & 10.97 & 8.30 & 8.95 & 9.01 \\
\hline 16.27 & nd & 15.20 & 16.24 & 15.33 & $\begin{array}{l}15.53 \\
\end{array}$ & 15.73 & 16.44 & nd & nd & 14.30 & 14.70 \\
\hline nd & nd & nd & 10.11 & 8.24 & 8.42 & 11.92 & nd & 10.32 & 10.35 & 11.25 & $\begin{array}{l}12.38 \\
\end{array}$ \\
\hline 7.68 & 8.69 & nd & nd & 10.77 & 13.19 & 12.44 & $\begin{array}{l}12.63 \\
\end{array}$ & 16.15 & 13.19 & 14.82 & nd \\
\hline $33 \cdot 5^{1}$ & $\begin{array}{ll}29.04 \\
\end{array}$ & 28.21 & 38.64 & 44.89 & $45 \cdot 72$ & 39.27 & 39.01 & $37.5^{8}$ & 35.61 & 39.03 & 35.97 \\
\hline nd & nd & nd & 51.81 & 50.92 & 51.43 & 47.67 & bd & 39.29 & 37.72 & 45.67 & 45.08 \\
\hline nd & nd & nd & nd & nd & nd & nd & nd & nd & nd & nd & 6.58 \\
\hline $9 \cdot 7$ & nd & 10,54 & 14.73 & 13,63 & nd & nd & nd & nd & 11.42 & 13.61 & nd \\
\hline nd & 7.62 & nd & 7.27 & 5.81 & 6.89 & nd & 6.07 & nd & & & 7.54 \\
\hline nd & nd & nd & nd & nd & nd & nd & & & & 18.36 & 9.97 \\
\hline 12.74 & 13.45 & $13.5^{2}$ & 15.73 & nd & 28.63 & $17 \cdot 30$ & $\begin{array}{l}16.33 \\
\end{array}$ & nd & nd & nd & nd \\
\hline 33.88 & 42.34 & 50.32 & 49.43 & & & & & & 36.84 & 38.55 & 37.62 \\
\hline nd & nd & nd & nd & 41.03 & 47.60 & 47.76 & 45.91 & 40.27 & $\begin{array}{l}34.59 \\
\end{array}$ & 34.8 & 34.55 \\
\hline 34.36 & 34.12 & 33.14 & 41.81 & 38.61 & 37.41 & 37.55 & 36.75 & 38.01 & 34.90 & 36.29 & 37.27 \\
\hline nd & 71.65 & 70.93 & $107.5^{8}$ & \begin{tabular}{|l|l}
102.76 \\
\end{tabular} & 66.37 & 44.54 & 68.14 & 65.72 & 69.01 & $93 \cdot 74$ & 85.61 \\
\hline nd & nd & nd & 6.66 & 9.09 & nd & 12.24 & 6.13 & 13.06 & $7 \cdot 30$ & 7.68 & 10.80 \\
\hline
\end{tabular}


Although the real cost of subsistence in Lithuania and in other countries in Eastern Europe was much higher than what de Zwart's basket assumes, its use provides a unique opportunity to assess the relative standing of Lithuanian wages in a broader context, encompassing the capital cities of most European countries. Although de Zwart's collection does not include data about the wages of skilled workers, this broad cross-country comparison allows new and important insights (see Table 6 and Fig. 1, where we visualise data from this table about selected European countries). We could expect to find that in 1927, the real wages of Lithuania's zimagorai was about half those in Germany, a third of those in Sweden and the UK, and a fifth of those in Denmark, which was interwar Lithuania's reference or model country. ${ }^{28}$ We could also expect that a construction labourer's wages in Warsaw did not differ much from those of their counterparts in the capitals of the Baltic States.

However, our findings about the relations between construction labourers' wages in Kaunas, on one hand, and Riga and Tallinn on the other, look puzzling. Even if wages in Riga were slightly higher than in Kaunas in 1927, since 1932, Kaunas zimagorai earned more than their occupational class peers in Latvia. In all years with data available on Estonia and Lithuania, Kaunas zimagorai earned more (see Table 6). Using for our analysis the mean wages of Kaunas unskilled industrial workers in the period 1930 to 1939 (see the two bottom rows in Table 2), we would get an even sharper picture of Lithuania's lead, because they were higher than zimagoras' wages.

We concede that our comparison will be incomplete until we have at our disposal data about the wages (measured in subsistence and welfare ratios) of Estonian and Latvian skilled construction workers. However, we would insist that our finding is valid both internally (for our sample including only zimagoras), and externally (for broader population of urban manual workers), because it is consistent with the findings of Vaskela, who compared the wages and standard of living of manual and white-collar workers

${ }^{28}$ e.g.: M. Drèmaitè, Progreso meteoras. Modernizacija ir pramonès architektūra Lietuvoje 1918-1940 m. (Vilnius, 2016), pp. 59-6o. 


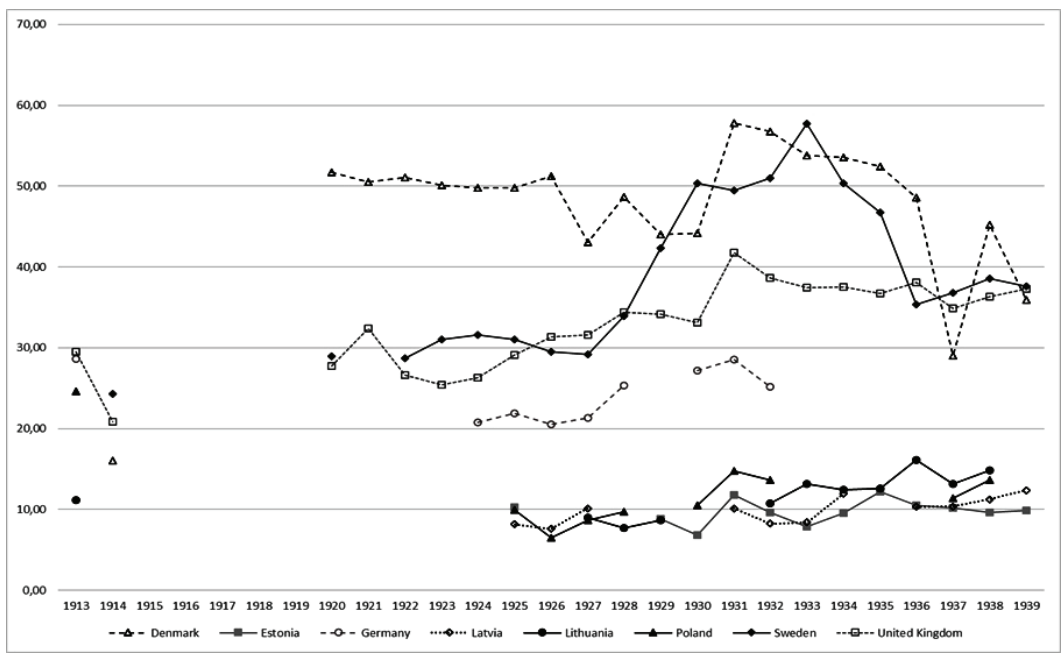

Figure 1. Real wages (measured in subsistence ratios) of unskilled construction workers in 1913-1939 in the capital cities of some European countries. For data for Lithuania, see Table 4; for other countries, see Table 6 (Zwart de, P., Leeuwen van B., Leeuwen-Li van, J., 'Labourers Real Wage' (2015), http://hdl.handle. net/10622/QK8VRF (accessed: 2019-08-26), IISH Dataverse,V1).

in the Baltic countries in 1938 to $1940 .^{29}$ As his research directly addresses a wider population than ours, it provides an opportunity to test the external validity of our findings about wages in the three Baltic countries, even if only for the final few years of the interwar period.

Vaskela compared the purchasing power of the mean wages of skilled and unskilled male and female workers, using as his yardstick the cost of subsistence 'minimal subsistence baskets' constructed by the statistical offices of Lithuania and Estonia. According to his final conclusion, 'monthly payment statistics in 1939 show that a Lithuanian industrial worker was paid about $19 \%$ more $13 \%$ in April 1940) than an Estonian worker, and about 8\% more (the same at the beginning of the 1940s) than a Latvian worker. ${ }^{3 \circ}$ If we compare the daily wages of skilled and unskilled male workers separately, then the wages of skilled Lithuanian male workers were

${ }^{29}$ G. Vaskela, 'Darbo užmokestis ir darbininkų bei tarnautojų šeimų gyvenimo lygis Lietuvoje, Latvijoje ir Estijoje 1938-1940 metais'.

${ }^{30}$ Ibidem, p. 35 . 
$16 \%$ higher than in Latvia, and $36 \%$ higher than in Estonia. The daily wages of unskilled male workers were higher in Latvia than in Lithuania (by $11 \%$ ), but Lithuanian unskilled industry workers earned more $(17 \%)$ than their Estonian counterparts.

\section{Conclusions and tasks for further research}

In answering our research questions (see introduction), we found that the real wages of unskilled construction workers in Kaunas were below the 1913 level during the first decade of independence, surpassing it by the end of the Great Depression in 1933 to 1935. In 1938, it was 33\% higher than before the First World War. The standard of living of skilled workers improved earlier and to a greater extent, with their real wages already approaching the prewar level in 1923, and surpassing it in 1931 (counting in de Zwart's subsistence ratios) by $71 \%$. During the depression, it did not fall below the 1913 level, but also had not recovered to the pre-depression level by 1938 .

In terms of international comparison, where only data on the wages of unskilled construction workers are available, the real wages of Kaunas construction workers in 1913 were below those in metropolitan cities in all countries with data available, except Turkey and Italy. However, they were no less than in St Petersburg and Moscow. This may be interpreted as evidence supporting the view that Lithuania was not a poor peripheral area of the Russian Empire, but one of its more advanced areas. In 1938, the wages of Lithuanian construction labourers were 6.3 times less than in the USA, three times lower than in Norway and Denmark, and about 2.5 times less than in the Netherlands, Sweden, Switzerland and the UK. They were only about $20 \%$ less than in France, and on nearly the same level as in Poland and Italy. They were higher than in Hungary, Yugoslavia and the USSR (Moscow). Most unexpectedly, we found that they were around 30\% higher than in Latvia (Riga), and $64 \%$ higher than in Estonia (Tallinn).

Although our findings about Latvia and Estonia are in line with the earlier results of Vaskela (2007), who compared the mean wages of workers and employees in the Baltic countries in 1938 to 
1940, they provide a puzzle and a challenge for further research, because they contradict what we might expect from the research available on the running order between interwar Baltic countries according to economic output per capita. By 1938, Latvia was the first, its GDP per capita (at purchasing power parity) surpassing Lithuania's by about 30\%, closely followed by Estonia. Lithuania is the laggard. ${ }^{31}$ According to our findings, the running order of unskilled construction workers' wages was different: during the second interwar decade of independence, Lithuania caught up and surpassed Latvia, while Estonia fell behind. Wage level and economic productivity, measured by gross domestic product (GDP), are known to be correlated. ${ }^{32}$ However, exceptions contradicting this correlation happen rather frequently, including the recent (in) famous case of the wage stagnation of real worker wages in the USA during recent decades, despite the significant growth in GDP during the same period. ${ }^{33}$ So we believe that we have discovered another case of an anomaly of this kind, which may be of interest not only to experts in Lithuanian history, but also to a broader international audience, including economists.

We hope we will be able to provide a compelling explanation of the 'Lithuanian anomaly' in future research. However, before testing, we need more evidence to document the phenomenon itself. For Lithuania, we need to fill in the data gaps about the wages of both skilled and unskilled construction workers. There are also large data gaps for Estonia and Latvia, including the year 1913, which is of special importance for a comparative assessment of the overall trajectory of economic growth during the interwar period in the Baltic countries. This work should also include replication research of de Zwart's findings about wages in Estonia and Latvia, as the ILO publications do not provide price data about all items in his basket.

${ }^{31}$ e.g.: G. Vaskela, Tautiniai aspektai Lietuvos ūkio politikoje 1919-1940 metais, pp. 9o-97.

${ }^{32}$ e.g.: L.P. de la Escosura 'International Comparisons of Real Product, 1820-199o: An Alternative Data Set', Explorations in Economic History, 37 (200o), p. 13.

${ }^{33}$ e.g.: L. Kenworthy, K. Bentele, 'How Trickle Down Can Fail: The U.S. Case', Progress for the Poor, Kenworthy, L. (ed.) (Oxford, 2011), pp. 19-32. 
Most importantly, further research should extend to a comparison of the real wages of construction craftsmen, using both subsistence and Allen's respectable baskets. After the collection of the missing evidence, we will be able to find the timing of the phenomenon under consideration: when did the wages of Lithuanian workers catch up with those of their counterparts in other Baltic countries? Then we will be able to proceed to search for the causes related to the particular circumstances of the place and time.

\section{Author Details}

Zenonas Norkus is a professor at the Institute of Sociology and Social Work in the Faculty of Philosophy, Vilnius University.

Aelita Ambrulevičiūtè is a senior research fellow at the Institute of Sociology and Social Work in the Faculty of Philosophy, Vilnius University.

Jurgita Markevičiūtè is a research fellow at the Institute of Sociology and Social Work in the Faculty of Philosophy, Vilnius University.

Address: Institute of Sociology and Social Work, Faculty of Philosophy, Vilnius University, Universiteto St. 9/1, Vilnius LT-01513, Lithuania

\section{Bibliography}

ALLEN, Robert C. 'Absolute Poverty: When Necessity Displaces Desire', American Economic Review, 107 (12) (2017), pp. 369o-3721.

ALLEN, Robert C. 'India in the Great Divergence', in: The New Comparative Economic History: Essays in Honor of Jeffery G. Williamson, T.J. Hatton, K.H. O’Rourke, A.M. Taylor (eds.) (Cambridge, 2007), pp. 9-32.

ALLEN, Robert C. The British Industrial Revolution in Global Perspective. 6th printing (Cambridge, 2012).

ALLEN, Robert C.' Consumer Price Indices, Nominal/Real Wages and Welfare Ratios of Building Craftsmen and Labourers, 126o-1913' (2001).

ALLEN, Robert C. 'The Great Divergence in European Wages and Prices from the Middle Ages to the First World War', Explorations in Economic History, vol. 38 (4) (2001), pp 11-447.

ALLEN, Robert C. et. al. 'Wages, Prices, and Living Standards in China 1738-1925: In Comparison with Europe, Japan, and India', Economic History Review, vol. 64 (2011), pp. 8-38. 
ALLEN, Robert C. MURPHY, Tommy E., SCHNEIDER, Eric. 'The Colonial Origins of Divergence in the Americas: A Labour Market Approach, Journal of Economic History, vol. 72 (2012), pp. 863-894.

ALLEN, Robert C. KHAUSTOVA, Ekaterina. 'Russian Real Wages Before and After 1917: in Global Perspective', University of Oxford, Discussion Papers in Economic and Social History, 158 (July, 2017).

ANDRIJAUSKAITE், Ugnè Marija. Miestu darbininkai ir organizuotas darbo judejimas Lietuvoje 1918-1940 m. Daktaro disertacija (Kaunas, 2017).

BALEVIČIUS, Zigmas. Darbininkų išnaudojimas buržuazineje Lietuvoje (Vilnius, 1950).

BALEVIČIUS, Zigmas. Darbininku padètis buržuazinëje Lietuvoje (Vilnius, 1960).

BUKELEVIČIŪTĖ, Dalia. et. al. Socialiniai pokyčiai Lietuvos valstybëje 1918-1940 metais (Vilnius, 2016).

CLARK, Gregory. A Farewell to Alms. A Brief Economic History of the World (Princeton, 2007).

ČERNIAUSKAS, Norbertas. Nedarbas Lietuvoje 1918-1940 metais. Daktaro disertacija (Vilnius, 2014).

Handbook of Cliometrics, Diebolt, C., Haupert C.m. (eds) (New York, 2016).

DRĖMAITE, Marija. Progreso meteoras. Modernizacija ir pramonès architektūra Lietuvoje 1918-1940 m. (Vilnius, 2016).

ESCOSURA Leandro Prados de la. 'International Comparisons of Real Product, 1820-199o: An Alternative Data Set', Explorations in Economic History, 37 (2000), pp. 1-41.

FOGEL, Robert William. The Escape from Hunger and Premature Death, 1700-2100. Europe, America and the Third World (Cambridge, 2004).

FRIDBERGAS, Šajè. Buržuazinès Lietuvos pramonè (Vilnius, 1988).

GAIGALAITÉ, Aldona. Darbininku judejjimo pakilimas Lietuvoje 1929-1934 metais (Vilnius, 1957).

GALOR, Oded. Unified Growth Theory (Princeton, 2011).

KENWORTHY, Lane., KEITH, Bentele. 'How Trickle Down Can Fail: The U.S. Case', in: Progress for the Poor, Kenworthy, Lane (ed.) (Oxford, 2011), pp. 19-32.

SCHOLLIERS, Peter., ZAMAGNI, Vera. Labour's Reward. Real Wages and Economic Change in 19th and 2oth-century Europe (Aldershot, 1995).

STRIMAITIS, K. Tarptautine darbo organizacija (Kaunas, 1936).

VASKELA, Gediminas. 'Darbo užmokestis ir darbininkų bei tarnautojų šeimų gyvenimo lygis Lietuvoje, Latvijoje ir Estijoje 1938-1940 metais' Lituanistika, vol. 53, 4 (72) (2007), pp. 19-35. 
VASKELA, Gediminas. Tautiniai aspektai Lietuvos ūkio politikoje 1919-1940 metais (Vilnius, 2014).

How Was Life? Global Well-Being Since 1820, Zanden Van, J.l., Baten, J., D'ercole, M.m., Rijpma, A., Smith, C., Timmer, M. (eds.) (Paris, 2014). ZWART Pim de, LEEUWEN Bas van, LEEUWEN-LI Jieli van., 'Labourers Real Wage' (2015), http://hdl.handle.net/10622/QK8VRF, (accessed: 2019o8-26), IISH Dataverse, V1.

\title{
LIETUVOS STATYBŲ DARBININKŲ REALIŲJŲ ATLYGINIMŲ \\ (IŠMATUOTŲ PRAGYVENIMO IR GEROVĖS SANTYKIAIS) 1913-1939 M. TARPTAUTINIS PALYGINIMAS
}

\author{
Santrauka \\ ZENONAS NORKUS, \\ AELITA AMBRULEVIČIUTTE், \\ JURGITA MARKEVIČIUTTE்
}

Šiame straipsnyje pateikiami du palyginimai: (1) lyginami kvalifikuotuc ir nekvalifikuotų darbininkų atlyginimai Kaune prieš Pirmaji pasaulinį karą ir tarpukario laikotarpiu; (2) to paties laikotarpio realieji atlyginimai Kaune lyginami su kvalifikuotų ir nekvalifikuotų darbininkų atlyginimais daugelio Europos šalių sostinėse. Antrajam palygimui naudojami rezultatai, kuriuos gavo tyrejjai, taikydami Roberto C. Alleno realaus darbo užmokesčio apskaičiavimo metodologiją. Joje nekvalifikuotų statybininkų (tarpukariu vadintų „zimagorais“) atlyginimai reprezentuoja visų nekvalifikuotų miesto darbininkų, o stalių arba dailidžių atlyginimai - visų kvalifikuotų darbininkų atlyginimus. Realūs atlyginimai matuojami pragyvenimo ir gerovès santykiais, kurie nurodo, kiek kartų atlyginimo perkamoji galia pranoksta pavienio darbininko (pragyvenimo santykis $=1$ reiškia absoliutų skurdą) ir jo šeimos (gerovés santykis $=1$ reiškia absoliutų skurdą) pragyvenimo ant absoliutaus skurdo ribos išlaidas. Absoliutaus skurdo lygị apibrèžia minimalus vartojimo krepšelis, kurio sudètis atspindi išgyvenimo tam tikrame regione sąlygas. Pagrindiniai rezultatai: 1. Pirmaji nepriklausomybės dešimtmetį Kauno „zimagorų“ realieji atlyginimai buvo mažesni palyginti su 1913 m., bet $1938 \mathrm{~m}$. juos pastebimai pranoko. 2. Nè vienais metais, apie kuriuos turime duomenų, nekvalifikuotų statybininkų atlyginimai nebuvo smukę žemiau absoliutaus skurdo lygio. 3. Realieji Kauno kvalifikuotų statybininkų atlyginimai smarkai pranoko $1913 \mathrm{~m}$. lygį dar iki didžiosios tarpukario pasaulio ekonominès krizès ir išliko aukščiau šio lygio netgi sunkiausiais krizės metais. 4. Kvalifikuotų ir nekvalifikuotų statybininkų atlyginimai Kaune 1913 m. nebuvo žemesni už atlyginimus Maskvoje ir Sankt Peterburge. 5. 1927-1929 m. 
nekvalifikuotų statybininkų realieji atlyginimai Kaune buvo mažesni už atlyginimus Maskvoje, bet kitame dešimtmetyje juos smarkiai pranoko, stalinistinei forsuotos industrializacijos politikai maskviečių atlyginimus nusmukdžius žemiau absoliutaus skurdo ribos. 6. Realieji nekvalifikuotų statybininkų atlyginimai Kaune antrajame tarpukario dešimtmetyje pranoko atitinkamus atlyginimus Rygoje ir Taline. Panašu rezultatą 2007 m. paskelbė Gediminas Vaskela, palyginęs darbininkų ir tarnautojų darbo užmokestį Lietuvoje, Latvijoje ir Estijoje 1938-1940 m. 